\title{
The Motherhood Wage Penalty High-Earning Women Are Doing Better Than Before
}

Rebecca Glauber

G ender inequality has declined precipitously over the past half-century, fundamentally altering women's, men's, and their children's lives. Despite these changes, women continue to pay a wage penalty for motherhood, earning about 5 percent less than equally-qualified childless women. Some now suggest that the gender wage gap is, in fact, a parenthood wage gap. In my recent study, I asked whether the motherhood wage penalty has declined over the past few decades. Are we witnessing a trend toward equality not just between women and men but also among women? The answers are mixed. The motherhood wage penalty began to decrease in the 1990s. ${ }^{1}$ The decrease, however, was most pronounced for high-earning women and smallest for lower-earning women. Median-earners fell somewhere in between. Today, high-earning women, or those who make close to $\$ 100,000$ per year, no longer pay a motherhood penalty. But low earners, or those struggling on $\$ 15,000$ per year, do. These changes in the motherhood wage penalty are reminiscent of the story of rising economic inequality, driven by gains at the top. Women at the top of the wage distribution have fared well over the past few decades, gaining various types of resources that have helped to ameliorate their work-family conflict.

\section{WAGE PENALTIES FOR MOTHERS COMPARED TO CHILDLESS WOMEN}

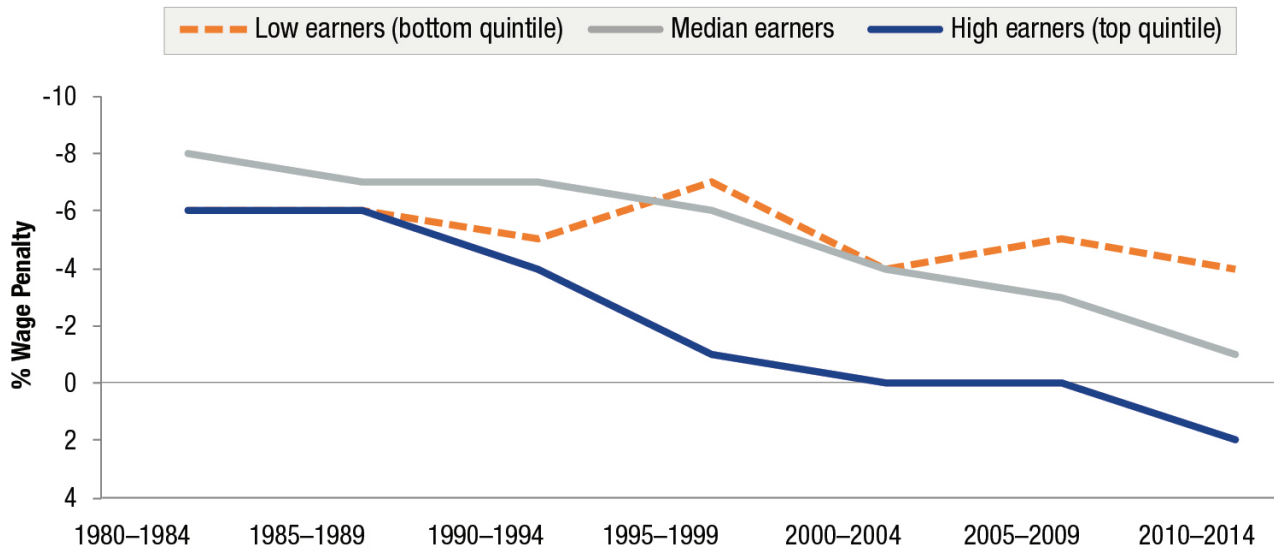

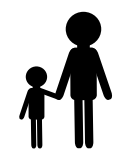

High-earning women no longer pay a motherhood wage penalty. Low earners do.

\section{Endnotes}

1 . The wage penalties are from multivariate regression models that control for differences between mothers and childless women in age, marital status, education, race-ethnicity, part-time work hours, occupation, and industry.

This snapshot summarizes the author's research in Rebecca Glauber, "Trends in the Motherhood Wage Penalty and Fatherhood Wage Premium for Low, Middle, and High Earners," Demography, 55, no. 5 (2018): 1663-80. Rebecca Glauber is an associate professor of sociology and a faculty fellow at the Carsey School of Public Policy at the University of New Hampshire (rebecca.glauber@ unh.edu).

Source: Current Population Survey, 1980-2014

Huddleston Hall • 73 Main Street • Durham, NH 03824 carsey.unh.edu $\bullet 603.862 .2821$
TTY UsERS: DIAL 7-1-1 OR

1-800-735-2964 (RELAY N.H.) 